DOI https://doi.org/10.30525/978-9934-588-79-2-1.17

\title{
КОНЦЕПТУАЛЬНІ ЗАСАДИ РОЗВИТКУ ЗАСОБІВ ПЕРЕДАЧІ ДАНИХ СПЕЦІАЛЬНОГО ПРИЗНАЧЕННЯ
}

\author{
Петрук С. М. \\ кандидат технічних наук, \\ заступник начальника науково-дослідного відділу \\ Центрального науково-дослідного інституту озброєння \\ та військової техніки Збройних Сил Украӥни
}

\section{Животовський Р. М.}

кандидат технічних наук, старший дослідник, начальник відділу-заступник начальника науково-дослідного управління Центрального науково-дослідного інституту озброєння та військової техніки Збройних Сил Украӥни м. Київ, Украӥна

Вступ. Досвід конфліктів останніх років показав недосконалість існуючої системи управління і зв'язку, основу якої складають засоби радіозв'язку (ЗРЗ).

Наукові дослідження, що проводяться, повинні вирішуватися в рамках реалізації концепції створення об'єднаної автоматизованої цифрової системи зв'язку (ОАЦСЗ) спеціального призначення, в основі якої покладена еталонна модель взаємодії відкритих систем OSI (Open systems interconnection basic reference model) i сучасні телекомунікаційні технології, засновані на застосуванні радіопристроїв з програмованою архітектурою (SDR - Software Defined Radio).

Тому метою доповіді $є$ обгрунтування концепції розвитку системи радіозв'язку спеціального призначення 3 урахуванням існуючих i перспективних підходів до побудови реконфігурованих радіозасобів.

Виклад основного матеріалу дослідження

\section{1. Системи (мережсі, канали) радіозв'язку}

Основні напрями наукових досліджень в галузі радіозв'язку повинні включати розробку принципів побудови систем радіозв'язку спеціального призначення різних рівнів застосування з метою забезпечення структурної стійкості мереж радіозв'язку до дії радіоелектронної протидії противника (РЕП) і засобів поразки на основі:

- поєднання прямих і комутованих ліній радіозв'язку малої і середньої дальності, що дозволяють здійснювати передачу інформації в обхід вузлів, що вийшли з ладу та радіоліній із-за дії зброї та РЕП; 
- комплексного використання радіоспектру в КХ та УКХ діапазонах, що дозволяє організовувати радіозв'язок з використанням різних механізмів поширення радіохвиль.

\section{2. Створення вузлів та центрів радіозв'язку}

Основні напрями наукових досліджень щодо створення вузлів та центрів радіозв'язку повинні включати розробку принципів побудови радіоцентрів різного призначення з метою забезпечення:

- модульної побудови уніфікованих радіоцентрів різних рангів, що забезпечують нарощування функціональних можливостей шляхом розмноження типових модулів;

- групового використання радіозасобів замість існуючого їх закріплення за радіонапрямами;

- цифрових способів автоматичного формування і реконфігурації топології радіомереж;

- забезпечення переходу від взаємодії по різнорідних стиках (як для ліній передачі даних, так і для ліній управління) до уніфікованого рішення на базі однієї із специфікацій Ethernet $[2,3]$.

\section{3. Комплекси $і$ засоби радіозв'язку}

Основні напрями наукових досліджень під час створення комплексів і засобів радіозв'язку повинні включати розробку принципів побудови радіозасобів різного призначення з метою забезпечення:

- створення приймальних, передавальних, антенно-апаратних комплексів і комплексів радіочастотного забезпечення;

- побудови комплексів і засобів радіозв'язку на основі концепції SDR i SCR (Software Cognitive Radio), що дозволяє в межах життєвого циклу апаратної бази розвивати функціональність пристроїв i ефективно використати радіочастотний спектр на основі вдосконалення програмного забезпечення, що забезпечує різні, у тому числі нові алгоритми;

- створення комплексів і засобів радіозв'язку, що забезпечують на програмно-апаратній платформі виконання мережами радіозв'язку функцій фізичного, канального і мережевого рівнів, а при управлінні функціонуванням мережі - також транспортного, сеансового представницького і прикладного рівнів.

\section{4. Антенно-апаратні комплекси}

Розробка антенно-апаратних комплексів що забезпечують можливість завадостійкого прийому інформації одночасно на декількох ділянках частот робочого діапазону від заданої кількості територіально рознесених кореспондентів на основі формування керованих просторових діаграм спрямованості спеціальної форми, реалізації необхідних значень чутливості по електромагнітному полю, живучості і надійності в умовах дії різного роду дестабілізують чинників [4]. 


\section{5. Програмно-апаратні комплекси радіопрогнозування $і$ плану- вання використання радіочастотного ресурсу.}

При створенні програмно-апаратних комплексів радіопрогнозування і використання радіочастотного ресурсу необхідно зосередитися на розробці:

- автоматизованих мереж оперативного радіопрогнозування;

- моделей розрахунку характеристик поширення радіохвиль в КХ діапазоні, у тому числі з використанням результатів зондування іоносфери;

- динамічних моделей дії природних і навмисних завад;

- програмно-методичного забезпечення для довготривалого, короткострокового і оперативного радіопрогнозування діапазону використовуємих частот;

- оцінка статистичних параметрів рівнів завад в реальному масштабі часу.

Висновки.

Запропоновані концептуальні рішення по системотехнічної та технологічної реконфігурації існуючої системи радіозв'язку дозволять:

1. Забезпечувати роботу в автоматизованих радіомережах у складі стаціонарних радіоцентрів інформаційно-телекомунікаційних вузлів, а також польових інформаційно-телекомунікаційних вузлів, забезпечуючи при цьому автоматичне ведення зв'язку.

2. Уніфікувати засоби і комплекси радіозв'язку із засобами зв'язку і автоматизації.

3. Забезпечити функціонування і управління приймально-передавальних комплексів як безпосередньо з апаратних, так і дистанційно.

4. Забезпечити автоматичну ретрансляцію сигналів відповідно до адреси кореспондента по вибору оптимального проходження радіохвиль.

5. Побудувати принципово нову, розподіленого типу і технологічно гнучку автоматизовану систему радіозв'язку.

\section{Лiтература:}

1. Шишацький А. В., Башкиров О. М., Костина О. М. Розвиток інтегрованих систем зв'язку та передачі даних для потреб Збройних Сил. Озброєння та військова техніка: науково-технічний журнал. Київ, ЦНДІ ОВТ ЗС України, 2015. № 1(5). С. 35-40.

2. Шишацький А. В. Аналіз принципів побудови програмованих радіостанцій країн НАТО. Збірник наукових праць ЦНДІ ОВТ 3С України. - Київ, ЦНДІ ОВТ ЗС України. 2015. Вип. № 1 (56). C. $162-173$.

3. Кузьмин Б. И. Концепция построения пакетных радиосетей в диапазоне ДКМВ-МВ. Электросвязь. 1993. № 5. С. 11-13. 
4. Каплин Е. А. Принципы построения и основы функционирования пакетных радиосетей в нестационарных средах передачи сообщений. Электросвязь. 1994. № 10. С. 62-70.

DOI https://doi.org/10.30525/978-9934-588-79-2-1.18

\title{
ОСОБЛИВОСТІ РЕАЛІЗАЦІЙ МОДЕЛЕЙ ДЕРЕВ КЛАСИФІКАЦІЙ НА ОСНОВІ СЕЛЕКЦІЇ ОЗНАК
}

\author{
Повхан I. Ф. \\ кандидат технічних наук, дочент, \\ дочент кафедри програмного забезпечення систем \\ Ужггородського наиіонального університету \\ м. Ужгород, Україна
}

Вступ Відмітимо, що станом на сьогоднішній день відомо біля трьох десятків готових програмних систем (ПС) для побудови різних типів моделей дерев класифікації (дерев рішень) у вигляді структур ЛДК (RStudio, RulQuest, DTTL v1.5, RLQTree, DCT v7, Precision Tree System, Edraw, SHAIDS, Weka, ЛАСТАН, АУРОН та інші) та лише одна ПС яка базується на концепції АДК (ОРІOН). Всі ці системи відрізняються прикладною спрямованістю задач що розв'язуються, методами та концептуальними засадами, різноманітним рівнем підтримки, причому багато з них знаходять у вільному (або частково вільному) доступі. Домінуючими підходами є системи на основі методів CART (спрямованих для розв'язку задач класифікації та регресивного аналізу), а також ПС на основі схеми C4.5/C5.0 та ії сучасних модифікації (для розв'язку задач розпізнавання та класифікації) та ID3.

Основна частина. Відмітимо, що алгоритм ID3 є однією з найпростіших схем для отримання дерев рішень 3 категоріальними класами та атрибутами (на основі ентропійного критерію), причому саме на основі ID3 і був написаний пізніше алгоритм C4.5. Хоча існує достатньо багато реалізаційних схем різних методів та підходів дерев рішень (дерев класифікації), одною з найбільш вживаних та такою що забезпечує необхідну ефективність $є$ алгоритмічна схема С5.0 (подальший розвиток концепції алгоритму C4.5), причому вона стала по факту галузевим стандартом для побудови моделей дерев класифікації оскільки підходить для більшості типів задачах безпосередньо прикладного характеру в сегменті аналізу різнотипної інформації. В порівнянні з більш досконалими та складними моделями машинного на- 